\title{
Investigating the Sociocultural Factors That Affect Learning a Second Language (on the Example of English)
}

\author{
Hatim H. Tawfiq \\ College of Sciences and Humanity Studies, Thadiq, Shaqra University \\ Shaqra, Saudi Arabia \\ Tel: 966-556-164-781_E-mail: hatim@su.edu.sa
}

Received: June 3, 2020

Accepted: July 9, 2020

Published: July 22, 2020

doi:10.5296/ijl.v12i4.17280

URL: https://doi.org/10.5296/ijl.v12i4.17280

\begin{abstract}
The present study investigates the sociocultural factors that affect second language learning. The investigation is built under five factors that are presumed to affect second language learning. The first factor is related to the effects of personality traits that are linked to second language learning, such as: self-efficiency, willingness, extraversion, and introversion, etc. The second factor pertains to motivation and second language learning. The third one is stereotyping and its effects on second language learning. The fourth is about social distance as a sociocultural factor of second language learning. And the fifth factor is about attitude. The study looks for how much effects do the factors mentioned so far have got in second language learning. A questionnaire is constructed to extract perceptions about the hypothesized factors from 62 participants. Responses are analyzed using Statistical Package for the Social Sciences (SPSS) to get statistical descriptions about the factors that mostly affect second language learning. The analytic statistics gives the following mean values for each factor: attitude $=20.58$, stereotype $=20.00$, motivation $=19.84$, social distance $=19.74$, and personality 18.85 . The study concludes with the consensus belief that attitude is a crucial factor of second language learning.
\end{abstract}

Keywords: Language learning, Personality, Motivation, Attitude, Social distance, Stereotyping 


\section{Al Macrothink}

International Journal of Linguistics

ISSN 1948-5425

2020, Vol. 12, No. 4

\section{Introduction}

The language that is learnt after one's first language is called second language (SL). Second language learning is a field that studies how learners of language learn that second language. The setting whereby the language is developed distinguishes between language acquisition and language learning. If the language is learnt in the environment where the language itself is used, and the learner endeavors to get by in that culture using that language, then the process is referred to as an acquisition. Acquisition happens through contact with the environment. Language skills, in this setting, are developed either on the street, through friendship, in informal situations. Learning, on the other hand, occurs in classrooms and requires intellectual skills. Learning concentrates on facts about the target language, such as the grammar and the linguistic knowledge of the language while acquisition offers skills to use the language. (Edmondson, 1999)

\subsection{Statement of the Problem}

The problem of concern in this paper is the sociocultural factors that restrict second language learning. There are some factors that restrict language learning. For instance, people coming from a higher-class background will probably outperform the middle-class ones in second language learning, since their opportunities for learning are more. The feeling of the first language social inferiority, and the social supremacy of the target language natives, both socially, economically, and culturally, enhances and encourages people to learn, acquire and master that language. The researcher in this paper investigates the effects of motivation, personality, stereotyping, social distance, and attitude in second language learning.

\subsection{Significant of the Study}

The investigation of this study is important to researchers of second language acquisition and second language teaching because it focuses on factors such as attitude, personality, and motivation, it gives insights about learners' characteristics that are very useful to language teachers. Researchers of language learning can find relative literature in this study to build their researches. Additionally, findings of the study are open for researchers" criticism that enriches the scope of language learning.

\subsection{Objectives of the Study}

The main objective of the study is to find out the sociocultural factor that mostly affects second language learning. This issue is decided according to the statistical description of the questionnaire.

\subsection{Hypothesis}

The paper concentrates on the following items as hypothesized to affect the second language learning: personality, attitude, stereotyping, motivation, and social distance.

\subsection{Question of the Study}

The study conscientiously addresses the following question: what are the sociocultural factors that affect second language learning? 


\subsection{Literature Review}

\subsubsection{The Sociocultural Factors of Second Language Learning}

The Sociocultural factors that affect language learning are attitude, stereotyping, social distance, motivation, and personality. There are other factors besides ones mentioned above, but this study concentrates mainly on attitude, stereotyping, social distance, motivation, and personality.

\subsubsection{Personality}

De Rad (2000) points out that personality is that characterize a unique individual. The model of Hippocrates and Galen (as cited in Dörnyei, 2005, p. 11) proposes four types of personality: phlegmatic, the calm and easygoing person, sanguine, the social people who prefer to socialize, the choleric, dashing, and impetuous people, and melancholic, the withdrawn and suspicious people. (Dörnyei, 2005). Studies of the good language learner connect personality factors such as self-confidence, taking risks, extroversion, and cooperation to proficient language learning. (Rubin, 1976). Extrovert and introvert are learners' characteristics that describe the learners' exposure to the surrounding. An extrovert is said to be unreserved, outgoing, cooperative, and more willing to share ideas with other peers whereas the introvert is always withdrawing and unwilling to accept the world around him. Studies of language acquisition show that extrovert is more successful to acquire the language easier than introverted learners. (Naiman, 1975). There are many studies, in language acquisition, that search for the link between language and personality. For example, Krashen (1985), and Skehan (1991). The important one is that of Ehrman (1996) where he suggests a perspicuous relation between personality and language acquisition. Personality characteristics that affect language learning are self-esteem, risk-taking and inhibition. Brodkey and Shore (1976) states that language learning and self-esteem are strongly connected. Inhibition is the case when something is restricted or prevented from happening or developing. This fact can be seen when learners commit mistakes and get frustrated by their weak performance. According to Zafar and Meenakshi (2012), the existence of a language ego is supposed to be a main barrier in the second language acquisition. Ego prevents improvement of language skills as the learner does not learn from the mistakes that he commits when learning the language. (Zafar \& Meenakshi, 2012)

\subsubsection{Motivation and Attitude}

Motivation is concerned with what makes people move to make a choice. Attitude is the power that gears the move/motivation toward the choice. There is a general fact that success depends on motivation, and that good language learners are highly motivated. (Ushioda, 2009). In 1968, a paper was presented at the TESOL convention by Gardener, an associate professor of psychology at the university of Western Ontario. The paper, which has a big impact on many studies conducted on motivation and second language acquisition, presents four important findings about motivation and second language acquisition: 1) Motivation is important in the second language acquisition. 2) Truly successful learners are motivated to become integrated in the target language community. 3) The learners" integrative motivation 
comes from the attitudinal characteristics in the home (active and passive role). 4) Second language acquisition involves taking on behavioral patterns of the target community. (Gardener, 1968). In 1972, Gardener and Wallace Lambert conduct systematic attempts to see the impact of attitude on second language acquisition. They define motivation as a construction made up of particular attitudes and identified two types of motivations: Integrative and instrumental. The integrative motivation (in which learners take on positive attitudes toward the target community) refers to learners who wish to integrate in the target community and in social interaction. The second type, instrumental motivation, refers to learners who wish to acquire the language for technical reasons. Negative attitude toward the second language community is always associated with decrease in motivation to acquire the second language, and accordingly to unsuccessful competent in the second language. (Brown, 2000). Learners" motivation involves three components: a sociocultural component, involves cultural and personal experiences, an educational component, involves the educational milieu, and an internal component, and involves beliefs and perceptions. Each of these components has its own effect on motivated behaviors; behaviors that demonstrate motivation. For example, the positive attitude toward a target community (sociocultural component) enhances acquisition (motivated behavior) of the language of the target community. (Helena, 2013)

\subsubsection{Stereotyping and Acculturation}

Culture offers a situation for people to form cognitive and affective behaviors. People comprehend veracity by the situation of their culture, they tend to believe that their own reality is the right perception. However, perception is always subjective. It involves sorting out ideas before accumulating in the memory, bringing about a novel type of perception. What appears to be a correct perception of an individual might be incorrect in the vision of other cultures. Misconceptions are likely to occur among cultures, but there would not be problems resulting from cross-cultural differences if people understand differing world views, implementing an approachable positive attitude toward different cultures. Cultural stereotypes affect thinking, speech, behavior, and peoples' interaction with one another. Stereotyping usually implicates some type of attitude toward the culture or language in question. Learners who have positive stereotypes toward the culture of the target language are likely to acquire that language. (Brown, 2000). It is important to understand the process of culture learning because learning a language implies, to some degree, learning another culture. This process involves the acquisition of a second identity. The creation of this new identity is known as acculturation. There are four stages of culture acquisition: The first stage is a period of excitement involving the newness of the surroundings. The second stage is called culture shock. It refers to a feeling of self-pity and anger for not understanding the new culture. The third stage is a stage of gradual recovery. People begin to accept the differences between cultures. The fourth stage is near or full recovery. Acceptance and assimilation of the new culture takes place here. (Brown, 2000). 


\subsubsection{Social Distance}

Social distance is the cognitive and affective closeness of two cultures that come into contact within an individual. It contains the following parameters: dominance, integration, congruence, permanence.

(1) Dominance: the idea that the target language is dominant/superior to the other. If L2 is dominant, learning will be difficult, if L2 is non dominant learning will be easier.

(2) Integration: the degree of socialization with the target culture.

(3) Congruence: refer to the similarity between the two cultures, if they are similar, the learning will be easier.

(4) Permanence: refer to the period that a learner could stay in the target culture, the longer he could stay, the easier he could learn the new language. The greater the social distance between two cultures, the greater the difficulty to learn its language, and conversely, the smaller the social distance, the better will be the learning situation. (Brown, 2000)

\subsection{Language and Culture}

An interpretation of the relationship between culture and language is essential for language learners; educators, and all those interested in language learning. The perception of different opinions concerning the relationship between culture and language is important for language teachers and learners as it clarifies the various conceptions toward language use. Additionally, these perceptions also help to know how language and culture affect the acquisition of a second language. There are many publications that focus on the aspects of culture in second language teaching. The most important periodical that is recently published is that of Byram (2008) which contains a set of essays conducted by innovative researchers in the field of language acquisition and culture, defining culture as common principles, beliefs, and behaviors of a community, and calling for the adoption of an intercultural approach to language teaching in the European schools. Hall (2002) discusses, from a sociocultural perspective, the theoretical support of current trends on the nature of language and culture learning, and the meticulous elucidation of Lange and Paige (2003) discusses multidisciplinary perceptions on culture teaching and learning, combining culture into the second language curriculums. The relationship between thought, language and culture was described in the 19th century by two German philosophers: Johann Herder and Wilhelm von Humboldt, and later, it was described by the American anthropologists: Franz Boas, Edward Sapir, and Sapir's student Benjamin Lee Whorf. Johann Herder presents the equation (one language $=$ one folk $=$ one nation) to express that nations" languages are reflected by the way its people think. The following lines explain his beliefs about language, thought, and culture. (If it be true that we...learn to think through words, then language is what defines and delineates the whole of human knowledge...in everyday life, it is clear that to think is almost nothing else but to speak. Every nation speaks...according to the way it thinks and thinks according to the way it speaks.) Wilhelm von Humboldt uses the following lines to describe the relationship between language and culture. (...there resides in every language a characteristic world-view ...By the same act whereby [man] spins language out of himself, he 
spins himself into it, and every language draws about the person that possesses it a circle whence it is possible to exit only by stepping over at once into the circle of another one.) The best perception of the relationship between language, thought and culture is seen in linguistic relativity which is formed by Sapir and Whorf. A hypothesis states that people perceive the world from different perspectives and according to the structure of their language.

\subsection{Language Acquisition and Culture Acquisition}

Language and culture are interlocked fields that mutually affect each other. According to Gleason (1961), languages are products and symbols of culture. Culture as a deep-rooted set of actions and forms of perceptions is crucial in the acquisition of a second language. Languages and culture are complicatedly interconnected so that one cannot break up the two without losing the significance of either language or culture. The acquisition of a second language is also the acquisition of a second culture except when learning the language for some instrumental reasons.

\subsection{Neo-Vygotskian Theory}

There is a new mainstream that emerges in second language acquisition. A conventional trend emerges from perspectives on SLT that are based on discourse and culture, connecting mind and learning, with social interaction and culture. The sociocultural theory, so-called the neo-Vygotskian theory, which arises from the Russian cultural psychology, paves the way for research and thinking in the field of second language development. The zone of proximal domain is the most applied pattern of the neo-Vygotskian theory in second language acquisition. The ZPD is a kind of activity in which a person is enabled to do more by some sort of support. (Herschensohn \& Young-Scholten, 2013). ZPD refers to the difference between what an individual achieve by himself and what he achieves by the support of his surroundings. (Yoon \& Kim, 2014). Sociocultural theory presumes that human thinking is regulated by the use and creation of mediating tools. (Swain \& Steinman, 2015). Vygotsky points out that the mediation of learning requires socialization between the more competent members and the less competent members of a group of people. (Yoon \& Kim, 2014).

\section{Method}

In this study, a questionnaire is constructed to elicit perceptions about the sociocultural factors that affect second language acquisition.

\subsection{Participants of the Study}

The study includes 62 participants. The following data were obtained: the participant's Educational qualification, the participant's Total years of teaching experience, and the Likert questions under five parts. The data from all 62 participants were included in the final analysis. 


\subsection{Participant Characteristics}

Participants of the study are different educators of English as a foreign language. Not all of them are $\mathrm{PhD}$ holders but some of them hold masters and bachelors. Their qualifications are from various universities in Sudan and Saudi Arabia.

\subsection{Sampling Procedures}

Method of sampling in this study is based on judgement sampling. Data were collected through an online survey using online service Google Documents. The Educational qualification breakdown of $\mathrm{BA}, \mathrm{MA}$ and $\mathrm{PhD}$ in this research is approximately 45.2 percent having MA degree $(n=28)$ to 33.9 percent having $\mathrm{PhD}(\mathrm{n}=21)$. The following teaching experience was detected in participants: $59.7 \%$ of participants had 16 and more, $27.4 \%$ of participants had 6 to 10 years and $8.1 \%$ of participants had 11 to 15 years teaching experience.

Table 1. Qualifications and experience

\begin{tabular}{lll}
\hline Variable & $\mathrm{N}$ & $\%$ \\
\hline Educational qualification & & \\
$\mathrm{BA}$ & 13 & 21.0 \\
$\mathrm{MA}$ & 28 & 45.2 \\
$\mathrm{PhD}$ & 21 & 33.9 \\
Total years of teaching experience & & \\
1 to 5 & 3 & 4.8 \\
6 to 10 & 17 & 27.4 \\
11 to 15 & 5 & 8.1 \\
16 and more & 37 & 59.7 \\
\hline
\end{tabular}

\subsection{The Questionnaire}

The data in the present study is analysed by using the Statistical Package for Social Sciences (SPSS). To perform this analysis, statistical testing in SPSS is exploited to analyse the data of second language instructors' perceptions about the research question and assumption. The Questionnaire, which is the main instrument for data collection, provides detailed ideas for SPSS to retrieve analytic tables that are supposed to help the researcher decide the most accepted hypothesis and help to get an image of findings and recommendations. There are five subscales, which are Personality, Motivation, Stereotyping, Social distance, and Attitude. The survey consisted of 27 multiple-choice questions, of which 25 were Likert-scale items ranging from $1=$ Strongly disagree to $5=$ Strongly agree. Six subscale total scores for the five items ranges from 5 to 25 . A score of 0-10 represents disagree, 11-16 moderate, and 17-25 agree. The table below shows that the entire subscales show good internal validity and reliability. 
Table 2. Reliability analysis

\begin{tabular}{lll}
\hline & Items & Cronbach's alpha \\
\hline Personality & 5 & 0.68 \\
\hline Motivation & 5 & 0.78 \\
\hline Stereotyping & 5 & 0.69 \\
\hline Social distance & 5 & 0.74 \\
\hline Attitude & 5 & 0.78 \\
\hline
\end{tabular}

\section{Results}

This section describes the statistical analysis of the data collected from the responds of the questionnaire, in addition to the interpretation and discussion of the results aiming to achieve the objectives of the study which concentrates on the sociocultural factors that affect second language acquisition.

\subsection{Personality}

Table 3. Personality

\begin{tabular}{lcc}
\hline & Mean & Standard Deviation \\
\hline $\begin{array}{l}\text { High self-esteem and willingness to take risks make second } \\
\text { language acquisition easier }\end{array}$ & 3.92 & 1.01 \\
\hline Language acquisition and self-esteem are strongly connected. & 3.94 & .99 \\
\hline $\begin{array}{l}\text { Extroverted learners acquire second language easier than } \\
\text { introverted learners }\end{array}$ & 3.56 & 1.08 \\
\hline $\begin{array}{l}\text { Taking risks in learning L2 (the risk of being wrong) enhances } \\
\text { language acquisition }\end{array}$ & 3.48 & 1.33 \\
\hline Low self-esteem impedes language acquisition & 3.95 & 1.02 \\
\hline
\end{tabular}

Self-esteem is one of the central powers of language learning. Low level of self-esteem creates an insecure learning situation that results in serious consequences such as avoiding taking the necessary risks to acquire communicative competence in the target language. (Ushioda, 2009). An average of the responses to all the questions of personality, in the table below, were strongly agree or agree. Rosenberg and Owen (2001) describe learners of low self-esteem as ineffectual and always overstating incidents as being unfavourable. The type of self-esteem, high or low, is an affective factor that plays a significant role in the process of second language acquisition. The statement that received the highest mean score was 3.95: "Low self-esteem impedes language acquisition" respondents agreeing or strongly agreeing. Two other statements share the next highest score "Language acquisition and self-esteem are strongly connected" was 3.94 and an average of 3.92 agree that the "High self-esteem and willingness to take risks make second language acquisition easier". However, "Extroverted learners acquire second language easier than introverted learners" and "Taking risks in learning L2 (the risk of being wrong) enhances language acquisition" were just slightly higher than the threshold score of 3.30, indicating that participants agreeing a moderate level. Extroversion and introversion are different personalities of language learners and there is a public belief that extroverted learners learn the second language faster than introverted 
learners, but the empirical researches of second language acquisition on which type of learners, extroverted or introverted, is likely to acquire the language effectively is inconclusive. Larsen-Freeman, 1991). Eilis, as cited in (Kayaoğlu, 2013), describes two hypotheses for the relationship between extroversion/introversion and language learning: the first is that extroverted are successful in communication as they have the basic interpersonal communicative strategies, and the second is that introverted learners develop cognitive academic aptitude, accordingly, they are better language learners. (Kayaoğlu, 2013). The ability to take risk is a trait of language learner personality. Beebe (1983) is the first scholar who searches about risk taking in language learning. She affirms that learners take risk whenever they are called on to perform in any learning situation. Furthermore, she states that risk-taking is a case where someone has an option between an alternative possibility of different desirability and where the consequence of the option is ambiguous and embroil fiasco.

\subsection{Motivation}

Table 4. Motivation

\begin{tabular}{lcc}
\hline & Mean & Standard Deviation \\
\hline $\begin{array}{l}\text { Negative attitude toward the language of a community restricts } \\
\text { the acquisition of its language. }\end{array}$ & 3.98 & 1.00 \\
$\begin{array}{l}\text { Positive attitudes toward the language of a community enhances } \\
\text { the acquisition of its language. }\end{array}$ & 4.16 & 1.12 \\
\hline $\begin{array}{l}\text { L2 learners who have higher integrative motivation attain higher } \\
\text { level of proficiency in L2 }\end{array}$ & 4.05 & 1.00 \\
$\begin{array}{l}\text { learners must be willing to identify with members of the target } \\
\text { ethno-linguistic group. }\end{array}$ & 3.50 & .86 \\
$\begin{array}{l}\text { Positive emotional experiences of L2 learning help students to } \\
\text { become competent language users. }\end{array}$ & 4.15 & .94 \\
\hline
\end{tabular}

Table 4 shows the result for motivation questions. The general average of the responses to all the questions were strongly agree or agree. Two statements that received the highest mean scores; if learners have a positive attitude toward the language of the community, the average of language acquisition was stated as 4.16. Most of the respondents gave an opinion as 'I agree' while answering this question. The positive attitude toward the language of community is a major factor of success in language acquisition. Learners with positive attitude would be more attentive in the learning process and take assessments more seriously, and they would find it more rewarding to simply go through the language. Consequently, they achieve more language competency. (Brown, 1988). The second statement that received the highest mean scores is that if the learners have a positive emotional experience of the second learning, the average of becoming competent language users was stated as 4.15. Most of the respondents gave an opinion as 'I agree' while answering this question. Second language learners use their positive emotions to build creative learning strategies, Conversely, negative emotions deactivate cognition. However, positive emotion is sometimes disadvantageous whereas negative emotions trigger cognition. Aspects of negative emotion such as: apprehension and shame, boost motivation, which in turn, enforces learners to make much effort to preclude 
failure, and accordingly become competent in the second language. (Pekrun, Goetz, Titz, and Perry, 2002). Another statement shares the next highest score; if the learners have higher integrative motivation the average of second language learning was stated as 4.05. Most of the respondents gave an opinion as 'I agree' while answering this question. It is presumed that second language learners' goals to learn the second language fall under two categories: the integrative category, which involves a positive temperament toward second language community and the desire to intermingle with that community, and instrumental category, in which a second language learner acquires a language of power that could lead to professional development, and to achieve practical goals, such as having a better career or a well-paying job. (Dörnyei, 2001). Integrative motivation stems from people's deeply ingrained predilections for the target culture. Learners with higher appeal to the target culture are intuitively committed to second language acquisition, what is more, they will search for opportunities to boost their second language competence to develop their cultural familiarity and attain integrative objectives. Hence, integrative motivation applies a positive impact on second language acquisition. (Zhang, Dai \& Wang, 2020). If the learners have a negative attitude towards the language of the community, the average of language acquisition, according to the analytic table below, was stated as 3.98. There is a general agreement among the participants that negative attitude toward the language of a community restricts the acquisition of its language, and that positive attitude toward the language of a community enhances its language acquisition. The analytic description attains an average of 3.50 of language acquisition if learners are willing to identify with members of the target ethnolinguistics group. Ushioda (2008) points out that, Gardener and Lampert in their researches on motivation and second language acquisition, think that learners should not only look for the linguistic knowledge of the second language, but also should be willing to identify with the target culture. Second language learner's willingness to identify with members of the target ethno-linguistic group enhances language acquisition. Sometimes, second language learners are required to accomplish social functions in the target language, such as developing friendship, acclimatizing to the social lifestyle of the target culture, and understand resources of attachment with the target community.

\subsection{Stereotyping}

Table 5. Stereotyping

Mean Standard Deviation

Positive stereotyping toward second language culture makes L2 acquisition easier

$4.00 \quad .92$

Stereotyping implies some type of attitude toward the culture of

L2

$3.84 \quad .81$

L2 learners need to implement an approachable positive attitude toward different cultures

$3.89 \quad .63$

L2 learners need to understand and appreciate cultural differences

Cultural stereotypes affect thinking, communication, behaviour, and peoples' interaction with one another 


\section{Mll Macrothink}

International Journal of Linguistics

ISSN 1948-5425

2020, Vol. 12, No. 4

Table 5 shows the result for Stereotyping questions. The overall average of the responses to all the questions were strongly agree or agree. The statement that received the highest mean score was 4.21: "L2 learners need to understand and appreciate cultural differences". The statement suggests that second language learners who understand and appreciate cultural differences are more likely to attain the second language competence. Competent use of a second language requires a level of awareness with the sociocultural setting of the second language. (Chan \& Wai, 2015). Two other statements share the next highest score, the first is "Cultural stereotypes affect thinking, communication, behaviour, and peoples' interaction with one another" received a considerable value of 4.06. Stereotypes of the target culture prevent learners from establishing an appropriate attitude and consequently affect the formation of cultural awareness. ( $\mathrm{Lu}, 2011)$. The second statement, which received an average of 4.0, shows a general agreement among the participants that "Positive stereotyping toward second language culture makes L2 acquisition easier". However, the statements, "L2 learners need to implement an approachable positive attitude toward different cultures" and "Stereotyping implies some type of attitude toward the culture of L2" were just between 3.80 and 4.00, indicating that participants agreeing a moderate level.

\subsection{Social Distance}

Table 6. Social distance

\begin{tabular}{lcc}
\hline & Mean & Standard Deviation \\
\hline $\begin{array}{l}\text { The bond between language and culture leads to greater } \\
\text { cultural understanding }\end{array}$ & 4.24 & .80 \\
$\begin{array}{l}\text { Greater appreciation of the second culture promotes L2 } \\
\text { acquisition and successful language learning. }\end{array}$ & 4.08 & .86 \\
$\begin{array}{l}\text { Successful language learners take on the mindset of the } \\
\text { speakers of the second language }\end{array}$ & 3.79 & .73 \\
$\begin{array}{l}\text { The more L2 learner is closer to the target culture, the more } \\
\text { maximizing is language acquisition }\end{array}$ & 4.03 & .89 \\
$\begin{array}{l}\text { The social and psychological distance between L1 and L2 } \\
\text { detains language acquisition }\end{array}$ & 3.60 & 1.02 \\
\hline
\end{tabular}

Table 6 shows the result for Social distance questions. Overall, an average of the responses to all the questions were strongly agree or agree. The statement that received the highest mean score was 4.24: "The bond between language and culture leads to greater cultural understanding" respondents agreeing or strongly agreeing. Mostly the stronger the bond is between the first language and second language culture, the best communicative competence in the second language is achieved. If second language learners wish to attain a level of competence in the second language, they must get cultural awareness with the target culture. There are two other statements that share the next highest score: "Greater appreciation of the second culture promotes L2 acquisition and successful language learning" was 4.08, and an average of 4.03 agrees that the "The more L2 learner is closer to the target culture, the more maximizing is language acquisition”. Appreciation and closeness of a second culture develop familiarity with cultural patterns and enhances communication skills. On the other hand, the 
statements "The social and psychological distance between L1 and L2 detains language acquisition" and "Successful language learners take on the mindset of the speakers of the second language" were just over 3.50 ; indicating that participants agreeing a strong level. According to Schuman's Hypothesis, "the larger the social distance between two communities, the more inconvenience the learner will find in second language acquisition. (Brown, 2000)

\subsection{Attitude}

Table 7. Attitude

\begin{tabular}{lcc}
\hline & Mean & Standard Deviation \\
\hline $\begin{array}{l}\text { There is a strong relationship between attitude toward second } \\
\text { language and success in second language learning. }\end{array}$ & 4.26 & .63 \\
\hline $\begin{array}{l}\text { L2 acquisition happens effectively when the learner's attitude } \\
\text { towards the target language is positive. }\end{array}$ & 4.18 & .76 \\
$\begin{array}{l}\text { Positive attitude toward L2 implies better foreign language } \\
\text { performance }\end{array}$ & 4.00 & .77 \\
$\begin{array}{l}\text { The affective factors (interest, values, and beliefs) influences } \\
\text { language acquisition. }\end{array}$ & 4.08 & .95 \\
$\begin{array}{l}\text { Learners various perceptions about their teachers, the target } \\
\text { culture, and the curriculum, shape the type of the attitude } \\
\text { toward language learning. }\end{array}$ & 4.06 & 0.95 \\
\hline
\end{tabular}

Table 7 shows the result for Attitude questions. Overall, an average of the responses to all the questions were strongly agree or agree. All question averages are greater than the 4.00 indicating that participants agreeing a strong level. Most of the respondents gave an opinion as "I agree" while answering those questions in the part attitude. Attitude is an important factor that influences language acquisition. Yi Liu (2014) form Yangtze university, China, states in his paper "Motivation and Attitude: Two Important Non-Intelligence Factors to Arouse Students' Potentialities in Learning English" that a learner of a second language is required to be psychologically prepared to acquire the second language. Attitude, which is incrementally linked to motivation, is a set of beliefs that is formed and developed gradually by the learner in each sociocultural context. A set of beliefs that play a crucial role in the learning process. There is a general agreement that positive attitude provides path for learning. There is a strong relationship between attitude toward second language and success in second language learning. Attitudes, negative or positive, are formed by factors such as: interactions, parents, and peers. (Liu, 2014). Learners of a second language attain sociolinguistic competence only when they get the ability to "live" in the second language, and this aptitude is connected to the learners' motivation and attitude toward the target community, which is in turn, connected to an incomparable success in the acquisition of the second language. (Geeslin \& Long, 2014) 


\section{Discussion}

Table 8. Result of descriptive analysis for sociocultural factors affecting second language acquisition

\begin{tabular}{llll}
\hline & $\mathrm{N}$ & $\mathrm{M}$ & $\mathrm{SD}$ \\
\hline Personality & 62 & 18.85 & 3.19 \\
\hline Motivation & 62 & 19.84 & 3.60 \\
\hline Stereotyping & 62 & 20.00 & 2.59 \\
\hline Social & 62 & 19.74 & 3.02 \\
\hline Attitude & 62 & 20.58 & 2.75 \\
\hline
\end{tabular}

According to the descriptive analysis of the sociocultural factors which have been investigated in the study, the factor that mostly affects second language acquisition and gets the highest value is attitude, receiving 20.58 in the descriptive analysis. Stereotype gets 20.00 and comes just after attitude. Motivation and social distance follow each otherer in the table above, there is $\mathbf{1 9 . 8 4}$ for motivation and 19.74 for social distance. Personality in this analysis comes as a final factor that affects language acquisition with a value of 18.85 .

\subsection{Enhancing Positive Attitude Toward Second Language Community}

Scholars, educators, and second language learners agree that positive attitude, toward the second community and its language, supports success of a second language learning. Positive thinking helps modifying learners' negative attitude toward the second language community. The positive thinking can be raised by learners' positive models such as language tutors and family members who can have open discussions with language learners, listen to their opinions, and give positive insights about learners' questions, which in turn, form a positive environment that eliminates patterns of negative thinking, and negative attitude toward the second language community.

\section{Conclusion}

Based on the results of this study, the attitude of the second language learner toward the second language appears to be the most factors that affect second language acquisition. There is a strong relationship between learners' attitude toward the second language and success in second language acquisition. Attitude is a series of values that play an important role in the acquisition process. The psychological preparation, which requires a positive attitude toward the second language, is a basic requirement for success in second language acquisition. The learners' positive attitude encourages learners to make serious endeavors to acquire the language. On the contrary, negative attitudes detain learning. Learners' various perceptions about their teachers, the target culture, and the curriculum, shape the type of the attitude toward language learning. Competence of a second language is reached when there is an ability to be in continuous contact with the second language. This continual contact depends on the learner's attitude toward the second community. 


\section{Ml Macrothink}

International Journal of Linguistics

ISSN 1948-5425

2020, Vol. 12, No. 4

\section{Acknowledgments}

I thank my colleagues for their academic support and effective cooperation.

\section{References}

Beebe, L. M. (1983). Risk-taking and the language learner. In H. W. Seliger, \& M. H. Long (Eds.), Classroom oriented research in second language acquisition (pp. 39-66). Rowley, MA: Newbury House.

Brodkey, D., \& Shore, H. (1976). Student personality and success in an English language program. Language Learning, 26, 153-162. https://doi.org/10.1111/j.1467-1770.1976.tb00267.x

Brown, H. D. (2000). Principles of language learning and teaching (4th ed.). White Plains: Longman.

Brown, J. (1988). Social psychology and second language learning: The role of attitudes and motivation. R. C. Gardner. London: Edward Arnold, 1985. Pp. xiv 208. Studies in Second Language Acquisition, 10(3), 419-421. https://doi.org/10.1017/S0272263100007634

Byram, M. (2008). From foreign language education to education for intercultural citizenship: Essays and reflections. Multilingual Matters, Clevedon.

Chan, W. M., Nagami, M., Walker, I., \& Bhatt, S. K. (Eds.). (2015). Culture and foreign language education: Insights from research and implications for the practice. Retrieved from https://ebookcentral-proquest-com.sdl.idm.oclc.org

Davies, A., \& Elder, C. (Eds.). (2004). The handbook of applied linguistics. Retrieved from https://ebookcentral-proquest-com.sdl.idm.oclc.org

De Raad, B. (2000). Differential psychology. In A. E. Kazdin (Ed.), Encyclopedia of psychology (Vol. 3, pp. 41-44). Oxford: American Psychological Association and Oxford University Press.

De, B. K., Lowie, W., \& Verspoor, M. (2005). Second language acquisition: An advanced resource book. Retrieved from https://ebookcentral-proquest-com.sdl.idm.oclc.org

Dörnyei, Z. (2001). Motivational Strategies in the language classroom (Cambridge Language Teaching Library). Cambridge: Cambridge University Press. https://doi.org/10.1017/CBO9780511667343

Dörnyei, Z. (2005). The psychology of the language learner: Individual differences in second language acquisition. Retrieved from https://search-proquest-com.sdl.idm.oclc.org

Edmondson, W. (1999). Twelve lectures on second language acquisition: Foreign language teaching and learning perspectives.

Ehrman, M. (1996). Understanding second language learning difficulties. Thousand Oaks, CA: SAGE Publications, Inc. https://doi.org/10.4135/9781452243436 


\section{Macrothink}

International Journal of Linguistics

ISSN 1948-5425

2020, Vol. 12, No. 4

Fasold, R., \& Connor-Linton, J. (Eds.). (2014). An introduction to language and linguistics. Cambridge: Cambridge University Press. https://doi.org/10.1017/CBO9781107707511

Gardner, R. C., \& Lambert, W. E. (1972). Attitudes and motivation in second language learning. Rowley, Mass: Newbury House Publishers.

Geeslin, K., \& Long, A. (2014). Sociolinguistics and second language acquisition. New York: Routledge. https://doi-org.sdl.idm.oclc.org/10.4324/9780203117835

Hall, J. K. (2002). Teaching and researching language and culture. Longman/Pearson, London.

Kayaoğlu, M. N. (2013). Impact of extroversion and introversion on language-learning behaviors. Social Behavior \& Personality: An International Journal, 41(5), 819-825. https://doi-org.sdl.idm.oclc.org/10.2224/sbp.2013.41.5.819

Krashen, S. D. (1985). The input hypothesis: issues and implications. London; New York: Longman.

Kroeber, A. L., \& Kluckhohn, C. (1952). Culture: A critical review of concepts and definitions. New York: Vintage Books.

Lange, D. L., \& Paige, R. M. (2003). Culture as the core: perspectives on culture in second language learning. Information Age Publishing, Greenwich, CT.

Larsen-Freeman, D., \& Long, M. (1991). An Introduction to second language acquisition research. London: Routledge. https://doi-org.sdl.idm.oclc.org/10.4324/9781315835891

Liu, Y. (2014). Motivation and attitude: Two important non-intelligence factors to arouse students' potentialities in learning English. Creative Education, 5, 1249-1253. https://doi.org/18.4236/ce.2014.514140.

Lu, L. (2011). The formation of cultural stereotypes in English language textbooks. In Y. Wang (Ed.), Education and educational technology, Advances in intelligent and soft computing (Vol. 108). Springer, Berlin, Heidelberg. https://doi-org.sdl.idm.oclc.org/10.1007/978-3-642-24775-0_110

Naiman, N., Frohlich, M., \& Todesco, A. (1975). The good second language learner. TESL Talk, 5, 58-75.

Rosenberg, M., \& Owens, T. (2001). Low self-esteem people: A Collective portrait. In T. Owens, S. Stryker, \& N. Goodman (Eds.), Extending self-esteem theory and research: Sociological and psychological currents (pp. 400-436). Cambridge: Cambridge University Press. https://doi.org/10.1017/CBO9780511527739.018

Rubin, J. (1975). What the 'Good language learner' can teach us. TESOL Quarterly, 9, 41-51.

Seli, H., \& Dembo, M. (2013). Motivation and learning strategies for college success. New York: Routledge, https://doi-org.sdl.idm.oclc.org/10.4324/9780203813836 


\section{Macrothink}

International Journal of Linguistics

ISSN 1948-5425

2020, Vol. 12, No. 4

Skehan, P. (1991). Individual differences in second language learning. Studies in Second Language Acquisition, 13(2), 275-298. https://doi.org/10.1017/S0272263100009979

Spada, P. L. (2013). How languages are learned (4th ed.). Oxford: Oxford University Press.

Swain, P. M., Kinnear, D. P., \& Steinman, L. (2015). Sociocultural theory in second language education: An introduction through narratives. Retrieved from https://ebookcentral-proquest-com.sdl.idm.oclc.org

Ushioda, E. (2008). Motivation and good language learners. In C. Griffiths (Ed.), Lessons from Good Language Learners (pp. 19-34). Cambridge: Cambridge University Press. https://doi.org/10.1017/CBO9780511497667.004

Ushioda, E. (2009). Self-esteem and foreign language learning. Newcastle, UK: Cambridge Scholars Publishing, 2007. Pp. xi 205. Studies in second language acquisition, 31(1), 129-130. https://doi.org/10.1017/S0272263109090081

Yoon, B., \& Kim, H. K. (Eds.). (2014). Teachers' roles in second language learning: Classroom applications of sociocultural theory. Retrieved from https://ebookcentral-proquest-com.sdl.idm.oclc.org

Zafar, S., \& Meenakshi, K. (2012). Individual learner differences and second language acquisition: A Review. Journal of Language Teaching \& Research, 3(4), 639-646. https://doi-org.sdl.idm.oclc.org/10.4304/jltr.3.4.639-646

Zhang, H., Dai, Y., \& Wang, Y. (2020). Motivation and second foreign language proficiency: The mediating role of foreign language enjoyment. Sustainability, 12, 1302.

\section{Appendix A}

Researcher Questionnaire

Dear sir/ Ma'am

Please fill out the questionnaire. Your opinion is highly appreciated. The questionnaire is formed to extract perceptions about second language acquisition. All responses you provide for this study will remain confidential. When the results are reported, you will not be identified by name or any other information that could be used to infer your identity. Only researchers will have access to view any data collected during this research. I appreciate your time and cooperation.

Personal information

1. Name (optional)

2. ELT Qualification $\mathrm{PhD}$ 
BA

Other

3. Total years of teaching experience

1 to 5

6 to 10

11 to 15

16 and more

Part One - Personality

1. High self-esteem and willingness to take risks make second language acquisition easier.

Strongly Disagree

Disagree

Neutral

Agree

Strongly Agree

2 Language acquisition and self-esteem are strongly connected.

Strongly Disagree

Disagree

Neutral

Agree

Strongly Agree

3. Extroverted learners acquire second language easier than introverted learners.

Strongly Disagree

Disagree

Neutral

Agree

Strongly Agree

4. Taking risks in learning L2 (the risk of being wrong) enhances language acquisition.

Strongly Disagree

Disagree

Neutral 
Agree

Strongly Agree

5. Low self-esteem impedes language acquisition.

Strongly Disagree

Disagree

Neutral

Agree

Strongly Agree

Part Two-Motivation

1. Negative attitude toward the language of a community restricts the acquisition of its language.

Strongly Disagree

Disagree

Neutral

Agree

Strongly Agree

2. Positive attitudes toward the language of a community enhances the acquisition of its Language.

Strongly Disagree

Disagree

Neutral

Agree

Strongly Agree

3. L2 learners who have higher integrative motivation attain higher level of proficiency in L2.

Strongly Disagree

Disagree

Neutral

Agree

Strongly Agree

4. L 2 learners must be willing to identify with members of the target ethno-linguistic group. Strongly Disagree 
Disagree

Neutral

Agree

Strongly Agree

5. Positive emotional experiences of L2 learning help students to become competent language users.

Strongly Disagree

Disagree

Neutral

Agree

Strongly Agree

Part Three - Stereotyping

1. Positive stereotyping toward second language culture makes L2 acquisition easier.

Strongly Disagree

Disagree

Neutral

Agree

Strongly Agree

2. Stereotyping implies some type of attitude toward the culture of L2.

Strongly Disagree

Disagree

Neutral

Agree

Strongly Agree

3. L2 learners need to implement an approachable positive attitude toward different cultures.

Strongly Disagree

Disagree

Neutral

Agree

Strongly Agree 
4. L2 learners need to understand and appreciate cultural differences.

Strongly Disagree

Disagree

Neutral

Agree

Strongly Agree

5. Cultural stereotypes affect thinking, communication, behavior, and peoples' interaction with one another.

\section{_ Strongly Disagree \\ Disagree \\ Neutral \\ Agree \\ Strongly Agree \\ Part Four - Social Distance}

1. The bond between language and culture leads to greater cultural understanding.

Strongly Disagree

Disagree

Neutral

Agree

Strongly Agree

2. Greater appreciation of the second culture promotes L2 acquisition and successful language learning.

Strongly Disagree

Disagree

Neutral

Agree

Strongly Agree

3. Successful language learners take on the mindset of the speakers of the second language.

Strongly Disagree

Disagree

Neutral 
Agree

Strongly Agree

4. The more L2 learner is closer to the target culture; the more maximizing is language acquisition.

Strongly Disagree

Disagree

Neutral

Agree

Strongly Agree

5. The social and psychological distance between L1 and L2 detains language acquisition.

Strongly Disagree

Disagree

Neutral

Agree

Strongly Agree

\section{Part Five-Attitude}

1. There is a strong relationship between attitude toward second language and success in second language learning.

\section{Strongly Disagree}

Disagree

Neutral

Agree

Strongly Agree

2. L2 acquisition happens effectively when the learner's attitude towards the target language is positive.

Strongly Disagree

Disagree

Neutral

Agree

Strongly Agree

3. Positive attitude toward L2 implies better foreign language performance. 
Strongly Disagree

Disagree

Neutral

Agree

Strongly Agree

4. The affective factors (interest, values, and beliefs) influences language acquisition.

Strongly Disagree

Disagree

Neutral

Agree

Strongly Agree

5. Learners various perceptions about their teachers, the target culture, and the curriculum, shape the type of the attitude toward language learning.

Strongly Disagree

Disagree

Neutral

Agree

Strongly Agree

- Please, briefly answer the following question: What are the sociocultural factors that affect language acquisition?

\section{Copyrights}

Copyright for this article is retained by the author(s), with first publication rights granted to the journal.

This is an open-access article distributed under the terms and conditions of the Creative Commons Attribution license (http://creativecommons.org/licenses/by/4.0/) 